İş ve İnsan Dergisi | The Journal of Human and Work

Y1l | Year: Ekim | October 2018

Cilt-Sayı | Volume-Issue: 5 (2)

ss | pp: $169-184$

doi: $10.18394 /$ iid. 443772

e-ISSN 2148-967X

http://dergipark.gov.tr/iid/

Araştırma Makalesi

\title{
Kendilik Değerlendirmeleri ve İş Yükü Fazlalığının Mesleki Tatmin Üzerine Etkisi: Avukatlar Üzerine Bir Araştırma
}

\author{
The Effect of Core Self-Evaluations and Excess Workload on Occupational \\ Satisfaction: A Study on the Lawyers
}

Simge Samancı ${ }^{\text {a }}$ H. Nejat Basım ${ }^{*}$,

MAKALE BİLGİSI

Anahtar Kelimeler:

Mesleki Tatmin, Kendilik

Değerlendirmesi, Is Yükü

Fazlaliğl, Avukatlar

Tarihler :

Geliș 13 Temmuz 2018

Düzeltme geliş 01 Ağustos

2018

Kabul 14 Ağustos 2018
ÖZ

Bu çalışmanın temel amacı, kişisel bir değişken olan kendilik değerlendirmeleri ile örgütsel bir değișken olan iș yükü fazlalı̆̆ının, mesleki tatmin üzerindeki etkisini bütünsel bir model aracılığıyla ortaya çıkarmaktır. Bu doğrultuda araştırma 482 avukattan anket yöntemiyle ve uygun ölçeklerle elde edilen verilerle gerçekleștirilmiștir. Araștırma sonucunda elde edilen bulgular çerçevesinde, kendilik değerlendirmesi ile mesleki tatmin arasında aynı yönlü, iş yükü fazlalığ ile mesleki tatmin arasında ise aksi yönlü ilișki olduğu tespit edilmiștir. Bunun yan sıra; kendilik değerlendirmelerinin mesleki tatmini ayn yönde etkilediği diğer taraftan, iş yükü fazlalı̆̆ının mesleki tatmin üzerinde herhangi bir etki yaratmadı̆̆ belirlenmiştir.

\section{A R T I C LE INF O}

\section{Keywords:}

Occupational Satisfaction,

Core Self-Evaluation, Excess Workload, Lawyers

Article history:

Received 13 July 2018

Received in revised form 01 August 2018

Accepted 14 August 2018

\begin{abstract}
A B S T R A C T
This study aims to identify the effect of core self-evaluation, a personal variable, and excess workload, an organisational variable, on occupational satisfaction through a holistic model. To this end, the study used data collected from 482 lawyers by using questionnaire method and appropriate scales. Per the study findings, a same directional correlation was observed between core self-evaluation and occupational satisfaction, whereas an opposite directional correlation was found between excess workload and occupation satisfaction. On the other hand, core selfevaluation was found to have a positive effect on occupational satisfaction, but excess workload had no effect on occupational satisfaction.
\end{abstract}

\footnotetext{
a İletişim kurulacak yazar, Öğr. Gör. Dr., Hacettepe Üniversitesi, Sağlık Hizmetleri Meslek Yüksekokulu, Ankara, Türkiye. E-mail: simgeatakli@hacettepe.edu.tr.ORCID:0000-0002-1284-381X

${ }^{*}, b$ Prof. Dr., Başkent Üniversitesi, İktisadi ve idari Bilimler Fakültesi, Ankara, Türkiye. E-mail: nbasim@baskent.edu.tr. ORCID: 00000002-3407-5049
} 


\section{GİRIŞ}

Örgütler, sahip oldukları çalışanlar sayesinde piyasada kendilerine bir yer edinerek, büyür ve gelişirler. Örgütün temellerini oluşturan çalışanların performanslarını artırmak, daha etkili ve verimli çalışmalarını sağlamak, örgütsel bağlılıklarını yükseltmek, tükenmişliğin önüne geçmek ya da motivasyonlarını artırmak gibi örgüt yararına gerçekleşmesi beklenen durumlar; çalışanların mesleklerinden tatmin olmaları ile mümkün olabilir. $\mathrm{Bu}$ sebeple mesleki tatminin örgütsel ve kişisel öncüllerinin bilinmesi, günümüz iş dünyasındaki çalışanlara ve yöneticilere pek çok katkı sağlayabilecektir.

Mesleki tatmin her ne kadar çalışanların mesleklerine yönelik duygu durumlarını ve değerlendirmelerini ifade etse de iş tatmini ile karıştırılmaması gerekir. İş tatmini meslekten ziyade çalışanın hali hazırda çalıştı̆̆ 1 işyerinde gerçekleştirdiği işe yönelik duyduğu histir (Lu, While \& Barriball, 2005: 211). Çalışanların mesleklerinden tatmin olmaları ise oldukça geniş kapsamlı bir kavramdır. Bu iki kavramın bireyde düşük olması, işe devamsızlık, tükenmişlik, motivasyon düşüklügü gibi benzer sonuçlara sebep olabilse de kişinin çalıştı̆̆ 1 meslekten tatmin olmaması mesleği bırakma gibi iş tatminsizliğine nazaran daha büyük ve keskin sonuçlar doğurabilmektedir (Lounsbury, Moffitt, Gibson, Drost \& Stevens, 2007: 174). Bu doğrultuda mesleklerinden tatmin olan çalışanlar, çalışma koşullarından memnun oldukları mesleklerinin gerektirdiği görevleri gerçekleştirirken daha istekli ve arzulu olacaklarından, mesleki tatminin ilk olarak örgütsel performans üzerinde etkili olabileceği düşünülmektedir (Bateman, 1983: 587). Mesleğine karşı memnuniyet duygusu geliștiren çalışan, işine yönelik daha fazla bilgi edinmek isterken işini de daha fazla sahiplenecektir (Velada \& Caetano, 2007: 285). Bu sebeple performans ve tatmin arasındaki ilișki göz ardı edilemez bir öneme sahiptir (Greene, 1972: 32). Diğer taraftan mesleklerine karşı tatmin, memnuniyet, hoşnutluk gibi olumlu duygular hisseden çalışanların bu olumlu duygularının örgütsel etkinlik ve verimlilik üzerinde de etkili olması beklenmektedir. Mesleklerinden tatmin olan çalışanlar genellikle örgüt lehine davranışlarda bulunup mantıklı kararlar aldıkları için örgütlerinin etkinliğini ve verimliliğini artırmaktadırlar (Palahang, Soltani, Nikfarjam \& Sharifi, 2012: 5553).

Örgütsel davranış değişkenlerinin tümünde olduğu gibi, bu derece geniş bir kapsama sahip olan mesleki tatmin kavramını öncülleri ile birlikte incelemek; öncülleri ile olan ilişkisini ortaya koymak, kavramın açıklanması ve anlaşılmasında büyük yarar sağlayabilecektir. Genel olarak bakıldığında, mesleki tatminin bireysel faktörler, örgütsel faktörler ve genel çevre faktörlerinden etkilendiği ifade edilebilir. Bu çalışmada kavramın, bir bireysel faktör olarak kendilik değerlendirmeleri ile iş yaşamının temel dinamiklerinden olan iş yükü ile olan ilişkisi ele alınmıştır. Diğer taraftan mevcut çalışma avukatlar üzerinde uygulanmıştır. Mesleğin temelinde, avukatlara sunulan farklı hak ve görevlerin yanı sira kanun ve bürokrasiye diğerlerinden daha fazla hâkim olmaları ve hukuksal anlamda iletişim kurdukları insanların hayatlarında belirleyici rollere sahip olmaları, mesleğe olan ilgiyi yükseltebilmektedir (Rumpf, 2010: 146). Aşı1rı iş yüklerine karşın yeterli ücret alamamalarına rağmen, avukatların mesleklerinin niteliğine yönelik farkındalıkları onların avukatlık mesleğine karşı tatmin olmalarını neden olabilmektedir (Dinovitzer \& Garth, 2007: 39). Bununla birlikte yüksek iş temposuna sahip olan avukatların kişilik özellikleri de mesleki tatminleri açısından değerlendirilmesi gereken bir durum olarak görülebilir. Avukatların müzakereci, uzlaşmacı, dışa dönük ve yüksek öz yeterliğe sahip bireyler oldukları ve bu tür kişilik özelliklerinden dolayı çalışkan ve üretken bireyler olarak nitelendirilebildikleri de görülebilir (Ellis, 1957: 194; McElhaney, 1982: 41). Yalnizca avukatların değil diğer sektör çalışanlarının da kendilerini nerede gördüklerinin ve nasıl değerlendirdiklerinin, mesleki tatmine ulaşmaları açısından, oldukça önemli olduğu ifade edilebilir. Bu kapsamda, çalışanların kendilik değerlendirmeleri sonucunda, belli bir ihtiyacı giderdiklerine ilişkin zihinlerinde oluşacak bir alg1, mesleklerinden tatmin olmalarını sağlayabilecektir (McElhaney, 1982: 41). Diğer yandan olması gerekenden fazla iş yüküyle baş etmek zorunda kalan bir çalışan, normal performansının altında kalarak pek çok hatalı iş ortaya çıarabilecek ve bireyde mesleğine yönelik olumsuz ruh hali oluşturabilecektir (RubioValdehita, Lopez-Nuez, Lopez-Higes \& DiazRamiro, 2017: 570). Bu noktalardan hareketle, kendilik değerlendirmesi ile iş yükü fazlalığının mesleki tatminin açıklanmasındaki rollerini bütüncül bir model çerçevesinde ortaya koymanın, mesleki tatmin kavramını anlama ve açıklamada önemli ipuçları sunacağını değerlendirmekteyiz.

\section{KURAMSAL CERÇEVE VE HIPOTEZLER}

\subsection{Mesleki Tatmin}

Bireyin sağlığını ve mutluluğunu kaybetmemesi için mesleğini sevmesi, ondan tatmin duyması gerekir (Hultqvist, Wästberg \& Eklund, 2017: 1). Meslekten duyulan tatmin, çalışanların mesleğe dair 
beklentileri ile o mesleği uygularken elde ettikleri sonuçların örtüşmesi ile çalışanda ortaya çıkan bir tür memnuniyet duygusudur (Hill, 2009: 55). Diğer bir ifadeyle mesleki tatmin, çalışanların mesleklerinin gelişmesine katkıda bulunmak için gösterdikleri olumlu tutum ve davranışlardır (Shawer, 2010: 598). Mesleğinden tatmin olmayan çalışanlarda çalışmak istememe, tükenmişlik, verimsizlik gibi olumsuz sonuçlarla karşı karşıya kalmak kaçınılmazdır (Angerer, 2003: 105).

Morgan'a (2010: 217) göre mesleki tatminin sağlanabilmesi için kişinin sahip olduğu yeteneklerin, meslekteki zorlukların üstesinden gelebilecek güçte olması gerekmektedir. Bu sayede birey mesleğine karşı olumlu algıya sahip olabilecektir. Wilcock (2006: 186) tatmin duyulan meslekleri kişilerin hayatlarını kurtarmaya yönelik olan meslekler, sahip olunan yetenekleri ortaya çıkarıp kullanmayı sağlayan meslekler ve kişisel gelişim sağlayan meslekler olmak üzere üç gruba ayırmıştır. Bu tür mesleklere sahip olan kişiler genel olarak mesleki tatmin duyan bireyler olarak görülmektedir.

Çalışanların mesleklerinden aldıkları tatmini artırmak genellikle o mesleğe ait koşulların iyileştirilmesine bağlıdır. Özellikle meslekte maddi olanakların yeterli oluşu, çalışanların mesleki tatminleri için önemli görülmektedir (Reineck \& Furino, 2005: 30). Yüksek mesleki tatmine sahip olan çalışların arzu edilen çalışma ortamına sahip oldukları ve bunun yanı sıra örgüte duydukları bağlılık ile verimliliğin de yüksek olduğu, düşünülmektedir (Fard, Nazari \& Yar, 2013: 191). Ayrıca yapılan çalışmalar sonucunda mesleki tatmini yüksek olan çalışanların düşük tükenmişliğe, depresyona, endişeye ve strese sahip oldukları da bulunmuştur (Raj \& Dean, 2005; Mezuk, Bohnert, Ratliff \& Zivin, 2011). Diğer taraftan mesleğinden tatmin olmayan çalışanlar, ya yaptıkları işe isteksiz olarak devam ederler ya da ilk firsatta iş değişikliğine yönelirler (Çavuşoğlu \& Savaş, 2016: 3). Daha ileri durumlarda ise meslek değişikliği yoluna dahi gidilebilmektedir.

Mesleki tatminin daha anlaşılabilir olabilmesi için öncüllerinin incelenmesi büyük önem taşımaktadır. Bireyin mesleğe yönelik ilgisi, yeteneği, mesleğin kişiye sunduğu firsatlar, mesleğin toplumda kabul edilen statüsü, iş koşulları, örgütün elde ettiği başarı ya da çalışanın meslektaşlarıyla kurduğu etkili iletişim mesleki tatmini etkileyen faktörler arasında sıralanabilmektedir (Koreki vd., 2015: 1; Gelard \& Chaman Khahi, 2015: 1791). Bu çalışmada mesleki tatmini etkileyen değişkenler arasından kendilik değerlendirmesine ve iş yükü fazlalığına odaklanılmıştır. Kişilik özellikleri birçok sonuç değişkeninde olduğu gibi, mesleki tatmini de derinden etkileyen bir öncül faktör olmaktadır. Zira bireyin meslekte çalışmaktan memnun olması, o meslekte kendini bulduğunu ve mesleğinin kişiliği ile uyumlu olduğunu gösterebilmektedir (Bacanlı, 2003: 338). Çünkü birey, kişiliğiyle uyumlu olmayan bir meslekte çalışmaktan tatmin olmayacak, dolayısıyla da o meslekte daha fazla çalışmak istemeyecektir. Bunun yanı sıra, iş yükündeki artışın bireyi tükenmişliğe, performansın azalmasına, strese, sinizme sürükleyebileceği ve mesleki tatmin üzerinde olumsuz etkilere neden olacağı beklenebilir (Walker, 1986: 35). Söz konusu değişkenler aşağıda kısaca açıklanmıştır.

\subsection{Kendilik Değerlendirmesi}

Kişilik, bireyin gösterdiği davranışlar üzerinde etkili olan, zamanla değişim göstermeyen, onu diğerlerinden ayıran, kendisine ve çevresine birey hakkında ipuçları veren ve bu ipuçlarıyla bireyin kimliği hakkında bilgiler sunan psikoloji temelli özelliklerdir (Morgan, 1998; Mount, Barrick, Scullen \& Rounds, 2005: 448). Kişilik, iş yaşamındaki davranışları etkileyen pek çok örgütsel çıktının da öncülüdür (Mansur, Ahmed, Ishaq, Ahmad \& Ali, 2011: 54). Mesleki tatmin, temelde bireyin kişiliği ile çalıştığı ortam arasındaki uyuma göre şekillenmektedir (Holland, 1985). Bu sebeple mesleki tatminin, kişilikten etkilenen örgütsel çıktılardan biri olduğu düşünülebilir.

Kişi, mesleğini seçerken becerilerini, yeteneklerini, tecrübelerini ve ilgi alanlarını gözden geçirip, kişiliğine en uygun mesleği tercih edebilmektedir (Odabaş, 2014: 129). Bunun için de kendilik değerlendirmesi yapabilmektedir. Kendilik değerlendirmesi bireyin kendisi ve çevresi hakkında yaptığı temel değerlendirmelerdir (Judge, Erez \& Bono, 1998: 168; Judge, Van Bianen \& De Pater, 2004: 326). Kavramın temelinde, bireyin kendisinin ne kadar değerli, yeterli ve yetenekli olduğuna ilişkin yaptığı olumlu ya da olumsuz değerlendirmeler vardır (Judge, Bono, Erez \& Locke, 2005: 257). Literatür taraması yapıldığında kavramın "temel benlik değerlendirmesi" (Gürbüz, Erkuş \& Sı ğrı, 2010), "öz benlik değerlendirmesi" (Süral Özer \& Tozkoparan, 2013), "temel kendini değerlendirme" (Şimşek \& Aktaş, 2014: 125) ya da "öz-kendilik değerlendirmesi”" (Şeşen, 2010) şeklinde farklı kullanımlarının olduğu görülmüss, bu çalışmada "kendilik değerlendirmesi" şeklinde kullanılmıştır. Kendilik, kişiliğin çekirdeğidir (Kohut, 1977). Diğer bir ifadeyle bireyin kim olduğunun özüdür (Deci \& Ryan, 1991: 238). Kendilik kelimesinin içeriğinde öz, çekirdek, temel gibi anlamların bulunması sebebiyle kavram, kendilik değerlendirmesi şeklinde kullanılmıştır. 
Kendilik değerlendirmesi, bireyi tanımaya yönelik olarak yapılan bir kişilik değerlendirmesidir. $\mathrm{Bu}$ sebeple de bireyin sahip olduğu özellikler, genel öz yeterlik, öz sayg1, duygusal denge ve kontrol odağı olmak üzere dört boyut altında incelenmektedir (Judge, 2009: 58). Genel öz yeterlik, kişinin görevlerini yerine getirirken, ortaya koyacağı genel yeteneklerine ve kabiliyetlerine olan inancidır (Brunborg, 2008: 97). Öz sayg1, bireyin kendini ne derece önemli, başarılı ve değerli olduğunu gördüğü ile ilişkilidir (Judge \& Bono, 2001: 80). Duygusal denge, diğer adıyla düşük nevrotiklik, bireyin sakin ve kendine güvenli duygu durumuna sahip olduğunu göstermektedir (Chang, Ferris, Johnson, Rosen \& Tan, 2012: 83). Kontrol odağ1 ise kişinin karşılaştığı olayların, dış güçlerden ziyade, kendi davranışlarına bağlı olarak gelişip gelişmediği hakkındaki değerlendirmesidir (Basım, Çetin \& Meydan, 2009: 60). Kendilik değerlendirmesi bu dört boyutun birleşiminden oluşmaktadır.

Kişinin kendilik değerlendirmesinin yüksek olması istenen bir durumdur. Çünkü bu sayede, kişi kendini hayata karşı olumlu, başarılı, kendine güvenli, etkili ve uyumlu olarak değerlendirecektir (Judge, Erez, Bono \& Thoresen, 2003: 304). Diğer taraftan düşük kendilik değerlendirmesine sahip bireyler yeteneklerine ve kabiliyetlerine güvenmedikleri için yaptıkları işte başarılı olamayacaklarını düşünerek, genellikle zorlu ve karmaşık işlerde bulunmak istemeyeceklerdir (Judge, Bono \& Locke, 2000). Buradan hareketle kendilik değerlendirmesi, birçok davranış değişkeninin öncülü olabilmektedir.

Diğer taraftan kişilik, gerçekleştirilmesi gereken iş yükü performansı ile ilişkili olmayabilir (Borman \& Motowidlo, 1993). Çalışanların, örgüt içerisinde özellikle uygulamalı olarak yaratıcılıklarını kullandıkları işleri gerçekleştirirken, kişiliklerinden ziyade motivasyonları önemlidir (Amabile, 1998: 79). $\mathrm{Bu}$ durumun sebebi sürekli rekabet halinde olan örgütler, genellikle çalışanların sonuçlandırdıkları işlere odaklanmakta ve kişilikleri göz ard1 edilebilmektedir (Yang, 2007: 881). Tavousi (2015: 66) yaptığı bir çalışmada da iş yükü ile kendilik değerlendirmesi arasında herhangi bir ilişkinin olmadığını da tespit etmiştir.

\section{3. İş Yükü Fazlalığı}

Çalışan bireyler örgüt içerisinde belli bir miktar işle karşı karşıya kalmaktadırlar. Genel olarak iş yükü, çalışan performansı ve tepkileri üzerinde etkili olan çeşitli baskılar şeklinde tanımlanmıştır (Weiner, 1982. 953). Diğer bir tanıma göre ise iş yükü, bireyin belli bir sürede sonuçlandırması gereken iş miktarıdır (Basch \& Fisher, 1998: 6). Genellikle örgüt çalışanlarının çalışma saatleri içerisinde sonuçlandırması gereken işlerin dağıtımı yapılırken, çalışanların sahip oldukları bilgi ve beceriler göz önüne alınmaktadır. İş yükünün temelinde iş yükü azlığı ve iş yükü fazlalığı olmak üzere iki boyut vardır (Maslach \& Leiter, 1997). İş yükü azlığı, çalışanın gereğinden az iş yükü ile karşı karşıya kalma durumu olarak ifade edilebilir (Karacaoğlu \& Çetin, 2015: 49). Diğer taraftan iş yükü fazlalığı ise kişinin belli bir süre içinde gerçekleştirmesi gereken toplam iş yükünün, gerçekleştirebileceği iş yükünden fazla olma durumu olarak tanımlanabilir (Punnakitikashem, Rosenberger \& Behan, 2008: 323).

İş yükü fazlalığı iş için gerekli olan zamanın yetersiz olması, farklı türdeki işlerin aynı kişi tarafından yapılacak olması, işin fiziki anlamda yorucu olarak nitelendirilmesi ya da işi gerçekleştirecek kişinin yeterli bilgi ve beceriye sahip olmaması gibi durumların sonucunda oluşmaktadır (Cam, 2004: 3). Bu durumlar kişinin mesai haricinde de belli bir planla çalışmasını gerekli kılmaktadır. Aksi halde yapılması gereken işler yetişmeyecek ve bu da çalışanın strese girmesine ve aile hayatının olumsuz yönde etkilenmesine sebep olacaktır (Crook, Taylor, Pallant \& Cameron, 2004: 33).

Aşırı iş yükü niceliksel iş yükü ve niteliksel iş yükü olmak üzere iki boyuttan oluşmaktadır (Cam, 2004: 3). Niceliksel iş yükünün temelinde, işi gerçekleştirmek için gerekli olan zamanın yetersizliği durumu vardır. Kişinin sorumlu olduğu işi gerçekleştirebilmek için sahip olduğu kısıtlı zaman, işleri sonuçlandırması için yeterli olmadığı için kişinin iş yükü artmakta ve bu artış niceliksel iş yükü fazlalığı olarak adlandırılmaktadır (Yılmaz \& Ekici, 2006: 35). Niteliksel iş yükü fazlalığı ise zamandan bağımsı olarak bireyin işi sonuçlandırabilmek için yeterli bilgi birikimine ve yeteneğe sahip olmaması durumudur (Yüksel, 2003: 215).

Çalışanların sahip oldukları beceriler ve yetenekler farklılık gösterebilir. $\mathrm{Bu}$ sebeple doğru çalışana doğru işin verilmesi, aşırı iş yükünü azaltabilecek bir önleme sahiptir (Punnakitikashem vd., 2008: 325). İş yükü fazlalığı tükenmişlik (Shanafelt \& Dyrbye, 2012), tatminsizlik (Goodman \& Januska, 2008: 32), depresyon (Arroba \& James, 1990), işten ayrılma niyeti (Jensen \& Messersmith, 2013) gibi pek çok değişkenin de öncülü olarak kabul edilmektedir. 


\subsection{Değiškkenler Arasındaki İlișkiler}

\subsubsection{Mesleki Tatmin ve Kendilik Değerlendirmesi İlişkisi}

Bireyin gerekli eğitimleri aldıktan sonra atıldı $\breve{g}_{1}$ meslek, para kazanıp, yaşamını idame ettirebilmesi açısından oldukça önemlidir. Burada tercih edilmek istenen meslek ile kişiliğin birbiriyle olan ilişkisine dikkat etmek gerekir (Erdoğan \& Ergün, 2011: 178). Sonuçta bireyin sahip olduğu kişilik özellikleri, mesleğe ya da işe yönelik tatmini de etkileyebilecektir (Lounsbury vd., 2003: 298).

Yazında mesleki tatmin ve kişiliği temel alan farklı çalışmaların yapıldığı görülmüştür. Martin ve arkadaşları (2005), yaptıkları bir çalışmada, yaşadıkları olaylarda kendi davranışlarının etkisi olduğunu düşünen iç kontrol odaklı bireylerin çalışırken karşılaştıkları zorluklarda daha etkin oldukları ve bu yüzden mesleki tatminlerinin de yüksek olduğunu ileri sürmüşlerdir. Kuzgun (1994: 51), yaptığı bir çalışmada bireyin mesleki faaliyetlerinin kişisel özelliklerine uygun olması halinde ancak mesleki doyuma ulaşılabileceğini savunmaktadır. Demirtaş, Cömert \& Özer (2011), öğretmen adayları üzerinde gerçekleştirdikleri bir çalışmaya göre ise öğretmenlerin öz yeterlik algıları ile mesleğe yönelik tutumları arasında pozitif ilişki olduğu tespit edilmiştir. Başka bir çalışmaya göre, pedagojik formasyon alan öğretmen adaylarının beş faktör kişilik özelliklerinden dışa dönüklük, yumuşak başlılık, deneyime açıklık ve sorumluluk kişilik boyutları ile mesleğe yönelik tutumları arasında ilişki olduğu ortaya çıkarılmıştır (Uslu, 2013: 233). Bozali ve Camadan'in (2018) öğretmenler üzerinde yaptıkları bir çalışmada ise mesleki tatmin düzeyleri ile mesleki benlik saygısı arasında olumlu yönde ilişki olduğu tespit edilmiştir.

Literatür taraması yapıldığında araştırmacıların genellikle iş tatmini ile kendilik değerlendirmesi arasındaki ilişkiyi incelemeye yöneldikleri görülmüştür (Laschinger, Purdy \& Almost, 2007; Peng vd., 2016; Tischler, Giambatista, McKeage \& McCormick, 2016). Burada mesleki tatmin ve iş tatmininin farklı kavramlar olduğunun belirtilmesi önem taşımaktadır. İş tatmini, çalışanların işlerine karşı geliştirdikleri olumlu duygu hali olarak ifade edilebilirken; mesleki tatmin, çalışanların mesleklerine yönelik olarak geliştirdikleri olumlu duygu hali olarak nitelendirilebilir.

Mesleki tatminin temelinde, mesleğe karşı ilgi, mutluluk, coşku gibi güçlü duygular göze çarpmakta ve mesleki tatminin iş tatmininden daha geniş bir kavram olduğu görülmektedir (Karaçam \& Pulur, 2018: 36). Kendisinin farkında olan ve mesleğin gerektirdiği özellikleri içinde barındıran çalışanlardan işlerinde başarılı, mutlu ve tatminkâr olmaları beklenebilmektedir (Gökdeniz \& Merdan, 2011: 23). Bu sebeple kendilik değerlendirmesi, bireyin benlik değerinin, etkililiğinin ve bireysel becerilerinin farkına varabilmesi açısından oldukça önemli olmaktadır. Kendilik değerlendirmesi olumlu olan birey kendini güçlü hissederek, olayları yönlendirmede kendini etkili eleman olarak görebilir ve böylece mesleğinden tatmin olması kolaylaşabilir. $\mathrm{Bu}$ düşüncelerden hareketle kendilik değerlendirmesinin, mesleki tatmini aynı yönde etkileyebileceği düşünülmektedir ve bu sebeple H1 hipotezi geliştirilmiştir.

Hipotez 1: Kendilik değerlendirmesi, mesleki tatmini aynı yönde etkilemektedir.

\subsubsection{Mesleki Tatmin ve İş Yükü Fazlalığı İlișkisi}

Çalışanların sahip olduğu iş yüklerinde ortaya çıkabilecek dengesizlikler beklenmedik olumsuz durumların yaşanmasına sebep olabilir. Bunlardan en bilinenleri çalışanda ortaya çıkan stres ve endişedir (Jones, 1998: 110). Aşırı iş yüküne maruz kalan çalışanlarda bir diğer görülebilecek durum ise mesleki memnuniyetlerinin azalmasidır.

Örgüt içerisinde işlerin artmasına rağmen sunulan kaynakların ve çalışan personelin sayısının yetersiz kalışı, çalışanların işlerine ve dolayısıyla mesleklerine yönelik daha az memnuniyet duymasına sebep olmaktadır (Omaç Sönmez \& Sevindik, 2013: 47). Bu durum biraz daha arttığında ise kişi, devam ettiği mesleğin kendine uygun olmadığını düşünerek, mesleğine olan bağlılığ azalacak ve mesleğini değiştirmeyi dahi düşünebilecektir (Flinkman, Leino-Kilpi \& Salanterä, 2010: 1428). Çalışanlar sorumluluklarında olan karmaşık görevlerin üstesinden gelmek isterken oldukça zor durumda kalabilmekte ve bu durum da mesleklerine karş1 memnuniyet duymalarına engel olabilmektedir (Rodríguez \& Martín, 2017: 129).

Fazla iş yüküne sahip bireyler gerekli zamanı kontrol edememekle birlikte kendilerini daha gergin, daha az memnun ve daha az üretken hissedebilmektedirler (Claessens, Van Eerde, Rutte \& Roe, 2004: 947). Çünkü işlerini bitirmek için kendilerine tanının süre yeterli olmayacak ve işlerini sonuçlandıramadıkları için de kendileri ve meslekleri ile ilişkili algıları olumsuz yönde etkilenebilir. $\mathrm{Bu}$ gerekçelerden hareketle fazla iş yükünün, mesleki tatmini aksi yönde etkileyebileceği düşünülmektedir ve bu sebeple H2 hipotezi geliştirilmiştir. 


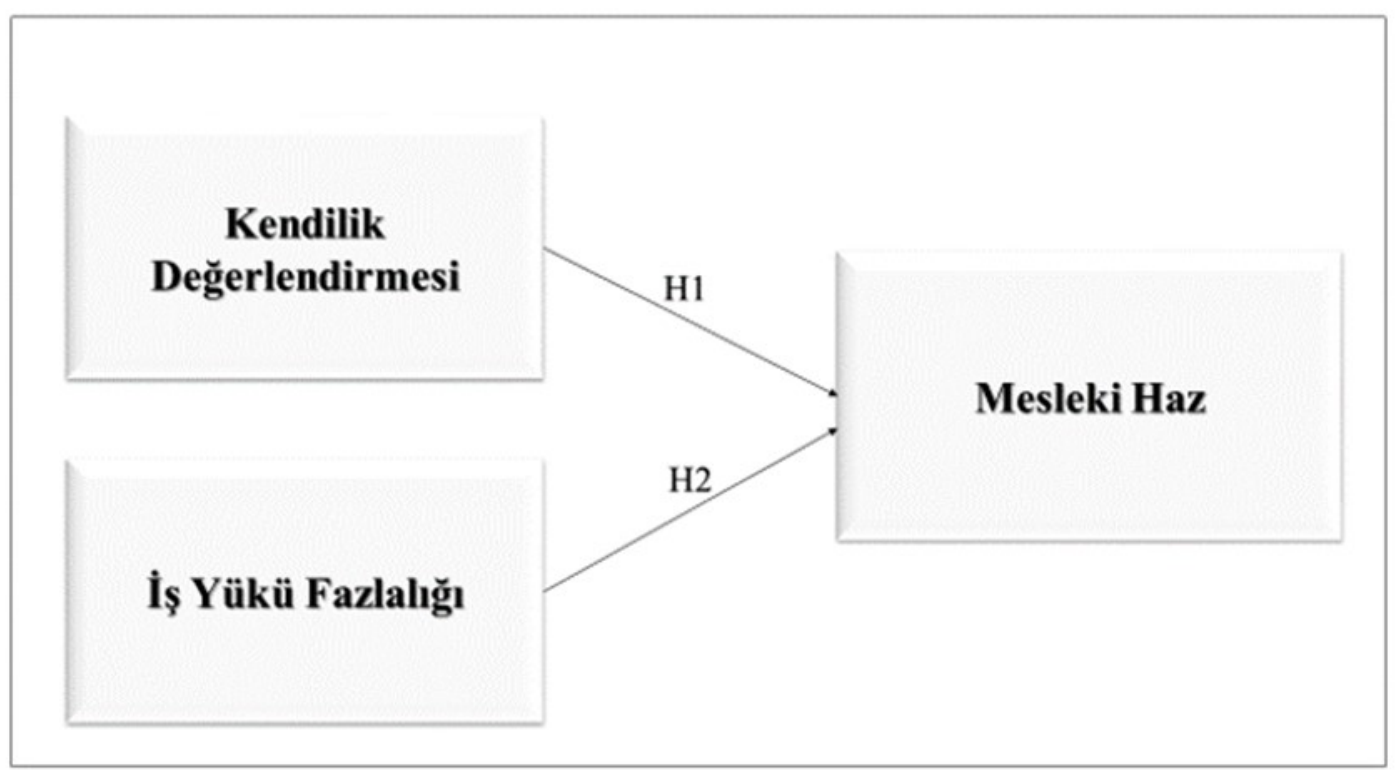

Şekil 1: Araştırmanın Modeli ve Temel Hipotezleri

Hipotez 2: İş yükü fazlalığı, mesleki tatmini aksi yönde etkilemektedir.

Anılan hipotezleri içeren araştırma modeli Şekil 1 'de sunulmuştur. (Bkz. Şekil 1)

\section{ARASTIRMANIN YÖNTEMI}

\section{1. Örneklem}

Yapılan bu çalıșma, avukatlar üzerinde gerçekleştirilmiştir. Çalışmanın avukatlar üzerinde gerçekleştirilme sebebi, Türkiye'nin her bölgesinde geçerliliği olan, farklı kişi ve konuları bir araya toplayabilen ve belirli bir mesai saati olmayan bir mesleğe mensup olmalarıdır. 2017 verilerine göre, Türkiye'de 106.496 avukat görev yapmaktadır (Türkiye Barolar Birliği). Araştırmaya katılacak avukatlara hızlı ve kolay ulaşabilmek adına kolayda örnekleme yöntemi kullanılmıştır. Avukatlara, epostaları vasıtasıyla ulaşılmış ve kendilerinden anketleri gönüllülük esası ile doldurmaları istenmiştir. Toplam 482 avukat gönüllü olarak çalışmaya katılmayı kabul etmiştir.

Katılımciların \%47.7'si (N=230) kadınlardan, kalanı $\quad(\%=52.3, \quad \mathrm{~N}=252) \quad$ ise erkeklerden oluşmaktadır. Katılımcıların yaş dağılımlarına bakıldığında ise yarısından çoğunun $(\%=54.8$, $\mathrm{N}=265)$ 23-35 yaş aralığında olduğu göze çarpmaktadır. Ankete katılan avukatların yaş ortalaması 36'dır. Diğer taraftan katılımcıların \%62.9'u (N=303) evli, \%37.1'i bekârdır ( $\mathrm{N}=179)$. Avukatların \%30.7'si ( $\mathrm{N}=148) \quad 0-4$ yillı mesleki tecrübeye sahipken, \%16.8'i (N=81) 15 y1l ve üzerinde mesleki tecrübeye sahip kişilerdir. Katılımcıların demografik özelliklerine ilişkin ayrıntılı bilgi Tablo 1'de verilmiştir. (Bkz. Tablo 1)

\section{2. Ölçüm Araçları}

İstatistiksel analizler için IBM SPSS 20.0 ve AMOS 23.0 paket programlarından yararlanılmıştır. $\mathrm{Bu}$ doğrultuda ilk olarak katılımcıların demografik özelliklerine ilişkin veriler analize tabi tutulmuştur. Sonrasında kendilik değerlendirmesi, iş yükü fazlalığı ve mesleki tatmin değişkenlerine ilişkin veriler analize tabi tutularak ortalama (X), standart sapma (S.S.) ve değişkenler arasındaki korelasyonalar incelenmiştir. Kategorik değişkenler sayı $(\mathrm{N})$ ve yüzde (\%) ile gösterilmiştir. Ölçeklere ilişkin geçerlik ve güvenirlik analizleri SPSS 20.0 ve AMOS 23.0 programları ile test edilmiştir. Değişkenler arasında ilişki olup olmadığı Pearson korelasyon katsayısıyla, etki olup olmadığı ise AMOS programiyla yapilan yol analizleriyle araştırılmıştır. Modeldeki değişkenleri ölçmek amacıyla üç farklı ölçekten yararlanılmıştır.

\subsubsection{Mesleki Haz Ölçeği}

Çalışanların mesleki tatminlerini ölçmek için Erdoğan (2013) tarafindan geliştirilen Mesleki Haz Ölçeği kullanılmıştır. Ölçeğin geçerlilik ve güvenilirlik analizleri yine kendisi tarafından yapılmıştır. Ölçek, 5'li likert tipinde, 1=Kesinlikle Katılmıyorum şeklinde ifade edilirken, 5=Kesinlikle Katılıyorum şeklinde ifade edilmekte ve toplam 7 maddeden oluşmaktadır. Ölçekten alınan yüksek puanlar katılımcıların mesleklerinden 
Tablo 1: Demografik Özellikler

\begin{tabular}{|c|c|c|c|c|c|}
\hline Özellikler & $\mathbf{N}$ & $\%$ & Özellikler & $\mathbf{N}$ & $\%$ \\
\hline \multicolumn{3}{|c|}{ Cinsiyet } & \multicolumn{3}{|c|}{ Medeni Durum } \\
\hline Kadin & 230 & 47.7 & Evli & 303 & 62.9 \\
\hline Erkek & 252 & 52.3 & Bekar & 179 & 37.1 \\
\hline Toplam & 482 & 100 & Toplam & 482 & 100 \\
\hline \multicolumn{3}{|c|}{ Yaș } & \multicolumn{3}{|c|}{ Mesleki Tecrübe } \\
\hline $23-35$ yaş & 265 & 55 & $0-4$ y1l & 148 & 30.7 \\
\hline $36-46$ yaş & 127 & 26.3 & $5-9$ y1l & 136 & 28.2 \\
\hline 47 ve üstü & 90 & 18.7 & $10-14$ y1l & 117 & 24.3 \\
\hline \multirow[t]{2}{*}{ Toplam } & 482 & 100 & 15 y1l ve üzeri & 81 & 16.8 \\
\hline & & & Toplam & 482 & 100 \\
\hline
\end{tabular}

duydukları tatminlerinin yüksek olduğunu göstermektedir.

Ölçeğin güvenilirliğini test etmek amacıyla yapılan analiz sonucunda Cronbach Alfa katsayıs1 .83 olarak tespit edilmiştir. Elde edilen bu değer, ölçeğin oldukça güvenilir olduğunu göstermektedir. Diğer taraftan katılımciların mesleki tatminlerini ölçek amacıyla kullanılan ölçeğin geçerliliğini test etmek için doğrulayıcı faktör analizi yapılmıştır. Bu analiz sonucunda CMIN/DF ve RMSEA uyum indekslerinin kabul edilebilir sınırlar içerisinde olmadığ1 görülmüştür $\quad(\mathrm{CMIN} / \mathrm{DF}=8.00$; RMSEA $=.12 ;$ GFI=.93; CFI=.93). Modifikasyon endeksleri incelendiğinde bazı değişkenlere ait hata terimlerinin ilişkilendirilmesinin modeli daha uyumlu hale getirdiği görülmüştür. İyileştirmeler yapilırken kuramsal olarak desteklenebilir olmasına dikkat edilmiştir. Aynı faktörü yordayan maddelerin hata terimleri arasında iyileştirmeler yapılması, kuramsal olarak desteklenebilen iyileştirmeler arasında görülmektedir (Meydan \& Şeşen, 2015: 82). İyileştirmeler yapilırken bu temel prensibe dikkat edilmiştir. $\mathrm{Bu}$ sebeple 2. madde ile 4 . maddenin ve 3 . madde ile 4 . maddenin hataları ilişkilendirilmiştir. Yapılan bu düzeltme ile tek faktörlü modele ait CMIN/DF ve RMSEA değerleri kabul edilebilir uyuma, diğerleri ise mükemmel uyuma ulaşmıştır (CMIN/DF=3.58; RMSEA=.07; $\mathrm{GFI}=.98 ; \mathrm{CFI}=.98)$.

\subsection{2. Öz Kendilik Değerlendirmesi Ölçeği}

Çalışanlarının kendilik değerlendirmelerini ölçmek için Judge ve arkadaşları (2003) tarafindan geliştirilen ölçek kullanılmıştır. Ölçek, özsaygı, öz yeterlik, kontrol odağ 1 ve duygusal denge boyutlarını içermektedir. Judge, Locke ve Durham (1997) bu dört kendilik değerlendirmesinin birleştirilmesi sonucunda ortaya genel bir kendilik değerlendirmesinin çıkabileceğini ileri sürmüştür. Tek boyutlu ölçek, Şeşen (2010) tarafindan Türkçeye uyarlanmış ve Öz Kendilik Değerlendirmesi adını almıştır. Ölçeğin geçerlilik ve güvenilirlik analizleri yine Şeşen (2010) tarafindan yapılmıştır. Ölçek 5'li likert tipindedir. 1=Kesinlikle Katılmıyorum şeklinde ifade edilirken, 5=Kesinlikle Katıllyorum şeklinde ifade edilmektedir. Ölçek toplam 12 maddeden oluşmaktadır. Ölçekten alınan yüksek puanlar katılımciların kendileri ile ilgili değerlendirmelerinin olumlu olduğunu göstermektedir. Ölçekte olumsuz yargı belirten ifadeler ise ters kodlanmıştır. Daha önce ülkemizde yapılan farklı çalışmalar da ölçeğin tek faktörlü 
yapısını doğrulamıştır (Arlı \& Avc1, 2017; Şeşen, 2010).

Araştırmada kullanılan ölçeklerin güvenilirliklerini test etmek amaciyla Cronbach Alfa katsayısından yararlanılmıştır. Yapılan güvenilirlik analizi sonucunda kendilik değerlendirmesi ölçeği için bu değerin .83 olduğu tespit edilmiştir. Anılan değer ölçeğin güvenilirliğinin yeterli düzeyde olduğunu göstermektedir.

Ölçeklerin geçerliliği AMOS paket programı aracılığıyla yapılan doğrulayıcı faktör analizi ile test edilmiștir. Katılımcıların kendilik değerlendirmelerini tespit etmeye yönelik olarak kullanılan ölçeğe birincil seviye tek faktörlü model analizi uygulanmıştır. Analiz sonuçları değerlendirildiğinde bazı uyum indekslerinin kabul edilebilir sinırlar içerisinde olmadığ 1 görülmüştür $(\mathrm{CMIN} / \mathrm{DF}=7.35 ; \quad \mathrm{RMSEA}=.11 ; \quad \mathrm{GFI}=.84$; CFI=.78). Faktör yapısındaki uyumu yükseltebilmek adına düzeltme indekslerine tekrar bakılmış ve tek boyutlu ölçeğin hata terimleri arasında iyileștirme yapılmasına karar verilmiştir. İyileştirmelerin kuramsal olarak desteklenebilir olması adına benzer boyutları ölçümlemeyi amaçlayan aynı alt boyutların hata terimleri ilişkilendirilebilmektedir (Meydan \& Şeşen, 2015: 82). Bu sebeple tek boyutlu ölçekte çeşitli hata terimleri arasında iyileștirmeler yapılmıștır. $\mathrm{Bu}$ sayede uyum iyiliği değerlerinin yükseldiği görülmüştür. Gerekli düzeltmelerin yapılmasının ardından tek faktörlü modele ait değerler kabul edilebilir sınırlara ulaşmıștır (CMIN/DF=3.69; $\mathrm{RMSEA}=.07$; GFI=.95; CFI=.95).

\subsection{3. İş Yükü Fazlalığı Ölçeği}

Çalışanların iş yükü fazlalıklarını ölçmek için Imoisili (1985) tarafindan geliştirilen ve Alam
(2016) tarafindan uyarlanan $\dot{I S S ̧}_{\text {Yükü Fazlalığl }}$ Ölçeği kullanılmıştır. Ölçek, Erdem, Kılınç ve Demirci (2016) tarafından Türkçeye uyarlanmış; geçerlilik ve güvenilirlik analizleri yapılmıştır. Ölçek 5'li likert tipindedir. 1=Kesinlikle Katılmıyorum şeklinde ifade edilirken, 5=Kesinlikle Katıliyorum şeklinde ifade edilmekte ve ölçek toplam 5 maddeden oluşmaktadır. Ölçekten alınan yüksek puanlar katılımcıların iş yüklerinin fazla olduğunu göstermektedir.

Ölçeğin güvenilirliğini test etmek amacıyla Cronbach Alfa katsayısından yararlanılmış ve bu değer .85 olarak tespit edilmiştir. Ulaşılan bu rakam, iş yükü fazlalığ 1 ölçeğinin istatistiksel olarak oldukça güvenilir olduğunu göstermektedir.

Katılımcıların iş yükü fazlalıklarını ölçek amacıyla kullanılan ölçeğin geçerliliğini test etmek amacıyla doğrulayıcı faktör analizi yapılmıștır. Yapılan analiz sonucunda bazı uyum indekslerinin kabul edilebilir sınırlar içerisinde olmadığı görülmüştür $(\mathrm{CMIN} / \mathrm{DF}=8.93 ; \quad \mathrm{RMSEA}=.19 ; \quad \mathrm{GFI}=.92$; CFI=.92). Faktör yapısındaki uyumu yükseltebilmek için tek boyutlu modelde bazı iyileştirmelerin yapılmasına karar verilmiştir. $\mathrm{Bu}$ doğrultuda 1 . madde ile 2 . maddenin ve 4 . madde ile 5. maddenin hataları ilișkilendirilmiștir. Yapılan bu düzeltme ile tek faktörlü modele ait tüm değerlerin mükemmel uyuma ulaştı̆̆ 1 görülmüştür (CMIN/DF=1.75; $\quad$ RMSEA=.04; GFI=.99; CFI=.99). Araştırmada kullanılan ölçeklere ilişkin uyum iyiliği değerleri Tablo 2'de gösterilmiştir. (Bkz. Tablo 2)

Tablo 2: Ölçeklerin Uyumuna İlişkin İstatistiksel Değerler

\begin{tabular}{cccc}
\hline Uyum İstatistiği & $\begin{array}{c}\text { Mesleki Tatmin } \\
\text { Ölçeği }\end{array}$ & Kendilik & İş Yükü Fazlalığı \\
\hline CMIN/DF & 3.58 & 3.69 & Ölçeği \\
RMSEA & .07 & .07 & 1.75 \\
GFI & .98 & .95 & .04 \\
CFI & .98 & .95 & .99 \\
\hline
\end{tabular}




\section{BULGULAR}

\subsection{Değişkenler Arası İlişkilere İlişkin Korelasyon Analizi Bulguları}

Araştırmanın temelini oluşturan modeli test ederek kendilik değerlendirmesi ve iş yükü fazlalığı ile mesleki tatmin arasındaki ilişkiyi ortaya çıkarmak için korelasyon analizi yapılmıştır. Korelasyon analizinin yapılabilmesi için öncelikle ölçeklerin genel ortalama puanları hesaplanmıştır. Elde edilen bulgulara göre değişkenler arasında anlamlı ilişki olduğu tespit edilmiştir $\left({ }^{*} p<.05 ; * * p<.01\right)$. Kendilik değerlendirmesi ile mesleki tatmin arasında aynı yönlü ilişkiye $(\mathrm{r}=.57 ; \mathrm{p}<.01)$ rastlanırken, iș yükü fazlalığ 1 ile mesleki tatmin $(\mathrm{r}=-.114 ; \mathrm{p}<.05)$ ve kendilik değerlendirmesi ile iş yükü fazlalığı $(\mathrm{r}=$ $.181 ; \mathrm{p}<.01)$ arasında aksi yönlü ilişki olduğu tespit edilmiştir. Korelasyon katsayıları dikkate alındığında ise kendilik değerlendirmesi ile mesleki tatmin arasındaki ilişkinin orta düzeyde güce sahip olduğu diğer taraftan iş yükü fazlalığı ile mesleki tatmin arasındaki ilişkinin önemsenmeyecek kadar düşük güce sahip olduğu değerlendirilebilir (Alpar, 2014: 356). Değişkenler arasındaki korelasyonlara ilişkin detaylı bilgi Tablo 3'te verilmiştir. (Bkz. Tablo 3)

Tablo 3 'ten elde edilen bir diğer sonuç ise ölçeklere ilişkin ortalama ve standart sapma değerleridir. Sonuçlar incelendiğinde tüm ölçeklerin ortalamanın üzerinde bir ortalamaya sahip olduğu ve birbirilerine oldukça yakın değerler aldıkları görülmüştür. Bunların arasından kendilik değerlendirmesinin diğerlerine nazaran daha yüksek $(\mathrm{X}=3.60, \quad \mathrm{~S} . \mathrm{S} .=.54)$, iş yükü fazlalığının ise diğerlerine nazaran daha düşük bir ortalamaya $(\mathrm{X}=3.56, \mathrm{~S} . \mathrm{S} .=.86)$ sahip olduğu tespit edilmiştir. Katılımcıların mesleki tatminlerinin de yine yüksek bir ortalamaya $(X=3.57, S . S .=.75)$ sahip olduğunu söylemek mümkündür.

\subsection{Hipotezlere İlişkin Bulgular}

Avukatların kendilik değerlendirmeleri ile iş yükü fazlalıklarının mesleğe yönelik tatminleri üzerindeki etkisini ortaya çıkarmak amacıyla yapısal eşitlik modeli analizi yapılmıştır. AMOS 23.0 yardımıyla hipotezleri test etmek maksadiyla çizilen ve yolları gösteren yapısal model Şekil 2'de verilmiştir. Çalışmada, verilerin normal dağılımına ilişkin analizleri sırasında basıklık ve çarpıklık değerleri esas alınmıştır (Tabachnick \& Fidell, 2013). Basıklık ve çarpıklık değerleri -1.5 ile 1.5 arsında olan verilerin normal dağılım gösterdiği tespit edilirken, tahmin yöntemi olarak maximum likelihood estimation (azami ihtimaliyet tahmini) kullanılmıştır. (Bkz. Şekil 2)

Yapısal modele ilişkin uyum iyiliği değerleri incelendiğinde değerlerin kabul edilebilir sınırlar içerisinde yer aldığı, görülmüştür (CMIN/DF=2.61; $\mathrm{RMSEA}=.05 ; \quad \mathrm{GFI}=.91 ; \quad \mathrm{CFI}=.95)$. Değişkenler arasındaki tespit etmek maksadiyla yapılan yol analizinin sonuçları ise Tablo 4'te gösterilmiştir. (Bkz. Tablo 4)

Elde edilen bu sonuçlara göre kendilik değerlendirmesinin mesleki tatmin üzerindeki etkisi anlamlı çıkarken $(p=.000)$, iş yükü fazlalığının mesleki tatmin üzerinde etkisinin anlamlı çıkmadığı görülmüştür $(p=.056) . \mathrm{Bu}$ sonuçtan hareketle kendilik değerlendirmesinin mesleki tatmin düzeylerini aynı yönde etkilediğine ilişkin $\mathrm{H} 1$ hipotezinin kabul edilebileceği, diğer taraftan iş yükü fazlalığının mesleki tatmin düzeylerini aksi yönde etkilediğine ilişkin $\mathrm{H} 2$ hipotezinin reddedilebileceği söylenebilir.

Tablo 3: Değișkenler Arasındaki İlișkilere Yönelik Bulgular

\begin{tabular}{cccccc}
\hline Değişkenler & $\overline{\mathbf{X}}$ & S.S. & $\begin{array}{c}\text { Kendilik } \\
\text { Değerlendirmesi }\end{array}$ & $\begin{array}{c}\text { İs Yüküi } \\
\text { Fazlalığı }\end{array}$ & $\begin{array}{c}\text { Mesleki } \\
\text { Tatmin }\end{array}$ \\
\hline $\begin{array}{cccccc}\text { Kendilik Değerlendirmesi } \\
\text { İş Yükiü Fazlalığı }\end{array}$ & 3.60 & .54 & 1 & $-.181^{* *}$ & $.570^{* *}$ \\
Mesleki Tatmin & 3.56 & .86 & $-.181^{* *}$ & 1 & $-.114^{*}$ \\
\hline
\end{tabular}

$\left({ }^{*} \mathrm{p}<.05 ; * * \mathrm{p}<.01\right)$ 


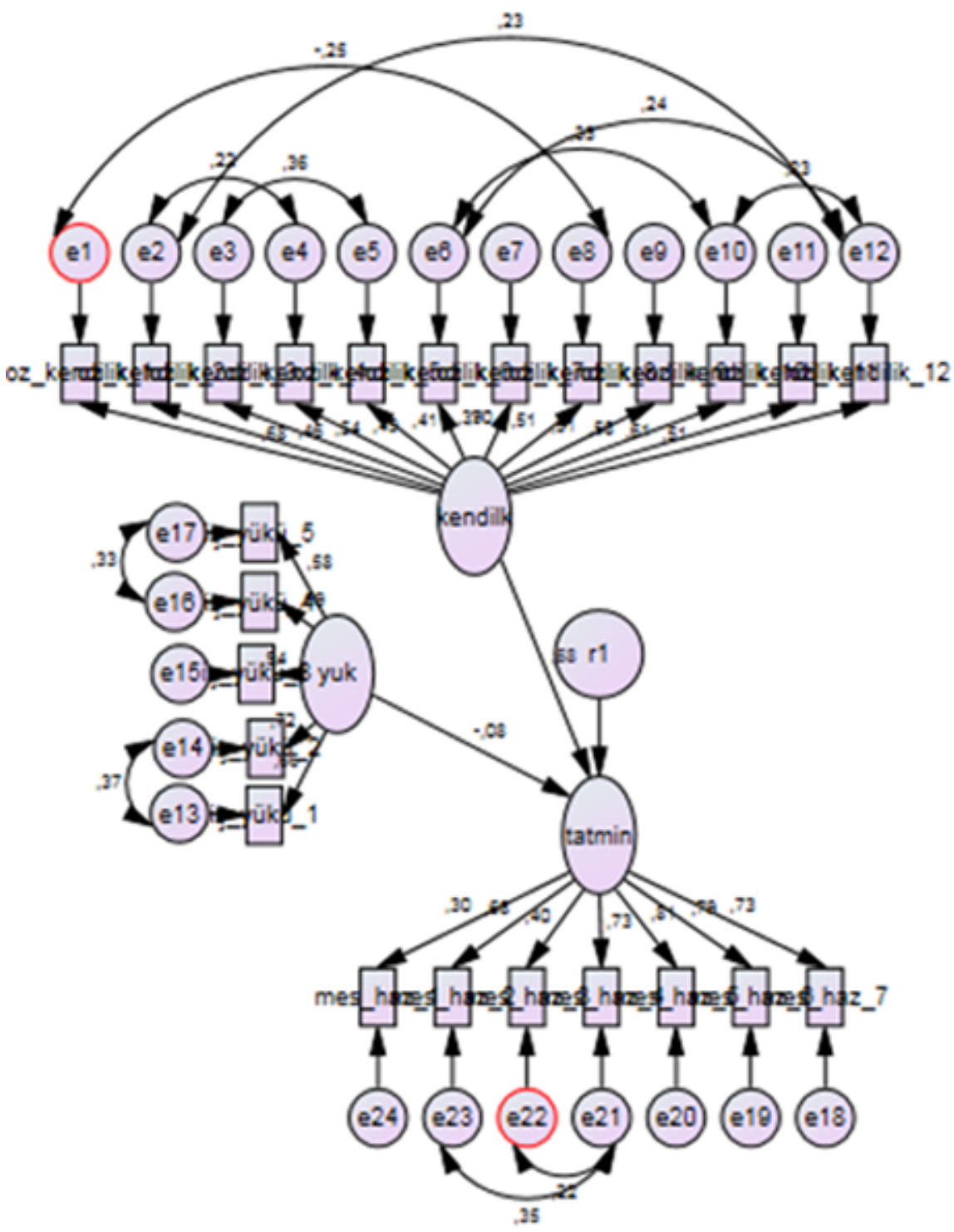

Şekil 2: Yapısal Model

Tablo 4: Yapısal Modelin Yol Analizine İlișkin Bulgular

Yapısal Modele İlișkin Yollar

$\begin{array}{ll}\text { Regresyon } & \text { S.E. } \quad P \\ \text { Katsayisı } & \end{array}$

İș Yủkủ Fazlalığı $\rightarrow$ Mesleki Tatmin

$-1.91$

.05

.056

Kendilik Değerlendirmesi $\rightarrow$ Mesleki Tatmin

10.59

.08

$.000^{* *}$

$\left({ }^{*} \mathrm{p}<.05 ;{ }^{* *} \mathrm{p}<.01\right)$ 


\section{TARTISMA VE SONUC}

Yapılan bu çalışmanın temel amacı, çalışma hayatında çok önemli bir yere sahip olan kendilik değerlendirmelerinin ve iş yükü fazlalığının mesleki tatmin üzerindeki rolünü ortaya çıkarmaktır. Daha önce ilgili alanda yapılan çalışmalara bakıldığında kişilik ile mesleki tatmin arasındaki ilişkiyi irdeleyen ya da iş yükü fazlalığı ile mesleki tatmin arasında ilişki olabileceğine yönelik ipuçları ortaya koyan çalışmaların olduğu görülmüş; fakat örgütsel ve kişisel anlamda bu değişkenleri aynı model içerisinde birleştiren bir çalışmaya rastlanmamıştır.

Model, örgütsel ve kişisel değişkenleri bir araya toplaması sebebiyle bütüncül bir bakış açısında sahiptir. Model içerisinde yer alan değişkenler arasındaki ilişkiler irdelenerek, yazına katkı sağlamanın yanı sıra yöneticilere ve çalışanlara uygulamalarda etkili olabilecek ipuçları sunarak farkındalık yaratmak hedeflenmiştir. Yapılan korelasyon analizi sonucunda mesleki tatmin ile kendilik değerlendirmesi arasında aynı yönlü ilişki olduğu, iş yükü fazlalığı ile arasında ise negatif yönlü ilişki olduğu tespit edilmiştir. $\mathrm{Bu}$ sonuç, kendilik değerlendirmesi olumlu olan bireylerin, mesleki tatminlerinin yüksek, olumsuz olan bireylerin ise tatminlerinin düşük olacağını; diğer taraftan fazla iş yüküne sahip bireylerin, mesleki tatminlerinin düşük, düşük iş yüküne sahip bireylerin ise mesleki tatminlerinin yüksek olacağını ortaya koymaktadır.

Çalışmanın uygulayıcılara ve yöneticilere katkıları değerlendirildiğinde çalışma, mesleklerinden tatmin olan bireylerle çalışmanın olumlu kendilik değerlendirmesine sahip olan çalışanlarla mümkün olduğunu ortaya çıkarmaktadır. Yöneticilerin örgütte çalışan kişilere yönelik ödül, prim gibi mesleki tatmini artırıcı eylemleri olabilse de pek çok sebeple bu tür tatmin edici etkenler her zaman gerçekleşmeyebilmektedir. Oysaki bireyin içerisinde bulunduğu ruh hali ve kendisine ilişkin gerçekleştirmiş olduğu olumlu öz değerlendirmeler hayatının büyük bir bölümünü geçirdiği mesleğinden tatmin olmasını etkileyebilecektir. Yapılan analizler, katılımcıların yüksek kendilik değerlendirmelerinin, mesleki tatminlerini artırıcı bir etkiye sahip olduğunu göstermiştir. Benzer şekilde daha önce yapılan çalışmalar kişilik ile meslek arasındaki uyumun, mesleki tatmini önemli ölçüde tahmin edebileceğini kanıtlamıştır (Xiao vd., 2014: 1). Srivastava, Locke, Judge ve Adams (2010) tarafından yapılan çalışmada da olumlu kendilik değerlendirmesinin mesleki tatmini artırdığı bulgusuna ulaşılmıştır. Bunların yanı sıra, Süral Özer ve Tozkoparan'ın (2013) yaptığı çalışmada ise kendilik değerlendirmelerinin mesleki doyumu ve yaşam doyumunu olumlu yönde etkilediği bulunmuştur. Olumlu kendilik değerlendirmesine sahip olan çalışanlar, örgüt içerisinde olumlu iletişim kurarak, kendilerine verilen görevleri etkin ve verimli şekilde tamamlamak isteyeceklerdir. Dolayısıyla çalışanların gerek yöneticileriyle gerek iş arkadaşlarıyla gerekse de müşterileriyle aralarındaki olumlu ilişsilerin oluşması ve kendilerine yönelik yaptıkları olumlu değerlendirmeler, çalışanların mesleklerini severek yapmaları açısından oldukça önemlidir. Zira kendilik değerlendirmesinin, mesleki tatmin üzerinde etkili olduğu ve kendisini yeterli, yetenekli, donanımlı gören bir çalışanın, mesleğini severek yapacağı ve mesleğinden tatmin olacağı ifade edilebilir.

Bireyin çalışırken yüksek performans gösterebilmesinin ve bunun yanı sira örgütsel etkililik ve verimliliğe katkı sağlayabilmesinin en önemli kriteri, bireyin mesleğini sevmesi yani meslekten tatmin olması olarak görülebilir. Daha önce yapılan çalışmalar da bu düşünceyi desteklemekte ve iş yükü fazlalığının mesleki tatmin üzerinde etkisinin olduğunu ileri sürmektedir (Bovier \& Perneger, 2003; Şahin \& Şahingöz, 2013, Pillay, 2009). Fakat yapılan bu çalışma ile kişinin sahip olduğu iş yükü fazlalığının, mesleki tatmin üzerinde herhangi bir etkisinin olmadı $\breve{g ̆}_{1}$ bulunmuştur. $\mathrm{Bu}$ bulgu, sahip olunan fazla iş yükü, bireyin mesleğini sevdiği, ondan tatmin olduğu, anlamina gelmemektedir. $\mathrm{Bu}$ sonuç, Van Steenbergen, Kluwer \& Karney (2011: 345-355) bulgularını desteklemektedir. Benzer şekilde bu bulgu, Tavousi (2015: 66) çalışmasının; çalışanların, iş yükü fazlalıklarını işe yönelik bir stres kaynağı olarak algılamadıkları, kendilerinde tatminsizlik yaratmadığı ve iş yükü fazlalığı sebebiyle olumsuz tepkiler vermedikleri bulgusuyla aynı yöndedir.

Yapılan bu çalışmanın sonucunda örneklem grubu olan avukatlara yönelik de birtakım bulgular elde edilmiștir. Elde edilen bulgular avukatların kendilik değerlendirmelerinin ortalamanın üzerinde olduğu, iş yüklerinin ortalamanın üzerinde bir değere karşılık geldiğini ve mesleki tatminlerinin de yine ortalamanın üzerinde olduğunu ortaya koymuştur. Mesleğin gereği olarak avukatların girişken, kendine güvenli, dışa dönük olma gerekleri, ülkenin tüm bölgelerinde faaliyetlerini mesai sınırlaması olmadan sürdürmeleri, mesleğe yönelik toplum içerisinde yerleşmiş olumlu algı ve meslekte maddi ve manevi kazanç elde etme potansiyeli düşünüldüğünde elde edilen bulguların beklentilerle uyumlu olduğu söylenebilir (Ellis, 1957; McElhaney, 1982). Diğer yandan avukatların kendilik değerlendirmelerinin mesleki tatminleri üzerinde etkili olduğunun bulunması, avukatlık 
mesleğinde kişinin kendisine ilişkin olumlu değerlendirme yapmasının bireyin mesleğinden zevk almasına yardımcı olduğu şeklinde yorumlanabilir. Richard'ın (2002) avukatlar üzerine yapmış olduğu çalışmada da benzer sonuçlara ulaştığı görülebilir. Avukatların iş yükü fazlalıklarının mesleki tatminleri üzerinde herhangi bir etkiye sahip olmaması ise iş yüklerinin niteliği ile açıklanabilir. Avukatların sahip oldukları iş yükleri genel itibariyle toplumsal ve bireysel sorunları çözmeye yöneliktir (McKenzie, 1992: 252). Bu sebeple iş disiplinine sahip bir avukatın iş yükü fazlalığının mesleğine yönelik tatmini üzerinde herhangi bir etkisinin bulunamaması düşündürücüdür.

Sunulan bulguların yanında araştırmada bazı sinırlılıklar da mevcuttur. Bu çalışmadan elde edilen bulgular çalışmamıza katılmayı gönüllü olarak kabul eden avukatlardan elde edilmiştir. Katılımcılara hızlı ve kolay ulaşabilmek adına kullanılan örnekleme yöntemi araştırmanın sınırlılığı olarak görülebilir. Dolayısıyla farklı bölgelerde, farklı mesleklerden, farklı büyüklüklerdeki örneklem grupları ile yürütülecek çalışmalar, sonuçların genellenebilirliğini artırabilecektir. Bunun yanı sıra araştırmaya katılan avukatların yarıdan fazlasının 23-35 yaş aralığındaki genç bireylerden oluşması araştırmanın sinırlılıkları arasında nitelendirilebilir. $\mathrm{Bu}$ doğrultuda gelecekteki çalışmaların daha büyük yaştaki avukatlara uygulanmasının yazına katkı sağlayabileceği düşünülebilir. Diğer taraftan ayrıca bir sosyal beğenirlik ölçeği oluşturulmadığından, sosyal beğenirlik sinırlılığı da sonuçların değerlendirilmesinde göz önünde bulundurulmalıdır.

\section{KAYNAKÇA}

Alpar, R. (2014). Spor, sağllk ve eğitim bilimlerinden örneklerle uygulamalı istatistik ve geçerlikgüvenilirlik. Ankara: Detay Yay.

Alam, M. A. (2016). Techno-stress and productivity: survey evidence from the aviation industry. Journal of Air Transport Management, 50(1), 62-70.

Amabile, T. M. (1998). How to Kill Creativity. Harvard Business Review, 76, 76-103.

Angerer, J. M. (2003). Job burnout. Journal of Employment Counseling, 40(3), 98-107.

Arl1, Ö. \& Avc1, A. (2017). Öz Kendilik Değerlendirmesinin Öz Liderlik Davranışları Üzerinde Etkisi: İlköğretim Öğretmenleri Üzerine Bir Araştırma. Mehmet Akif Ersoy Üniversitesi Sosyal Bilimler Enstitüsü Dergisi, 9(22), 455-468.

Arroba, T. \& James, K. (1990). Reducing the Cost of Stress: An Organizational Model. Personnel Review, 19(1), 21-27.

Bacanlı, F. (2003). Mesleki grup rehberliğinin benlik ve meslek kavramlarının bağdaşımına etkisi. Kuram ve Uygulamada Eğitim Yönetimi, 35(35), 336-359.

Basch, J. \& Fisher, C. D. (1998). Affective eventsemotions matrix: A classification of work events and associated emotions. The First Conference on Emotions in Organizational Life'da sunulan bildiri, San Diego.

Basım, H. N., Çetin, F. \& Meydan, C. H. (2009). Kişilerarası çatışma çözme yaklaşımlarında kontrol odağının rolü. Selçuk Üniversitesi Sosyal Bilimler Enstitüsü Dergisi, 21, 57-69.

Bateman, T. S. \& Organ, D. W. (1983). Job satisfaction and the good soldier: The relationship between affect and employee "citizenship". Academy of Management Journal, 26, 587-595.

Borman, W. C. \& Motowidlo, S. J. (1993). Expanding the criterion domain to include elements of contextual performance. N. Schmitt \& W. Borman (Eds.), Personnel selection in organizations içinde (ss.7198). New York: Jossey-Bass.

Bovier, P. A. \& Perneger, T. V. (2003). Predictors of work satisfaction among physicians. The European Journal of Public Health, 13(4), 299-305.

Bozali, S. \& Camadan, F. (2018). Okul öncesi öğretmenlerinin mesleki haz düzeylerinin açıklanmasında mesleki benlik saygısı ve rol fazlası davranışların rolünün yapısal eşitlik modeliyle incelenmesi. Baskent University Journal of Education, 5(1), 27-39. 
Brunborg, G. S. (2008). Core self-evaluations: A predictor variable for job stress. European Psychologist, 13(2), 96-102.

Cam, E. (2004). Çalışma yaşamında stres ve kamu kesiminde kadın çalışanlar. Journal of Human Sciences, 1(1) 1-10.

Chang, C., Ferris, D. L., Johnson, R. E., Rosen, C. C. \& Tan, J. A. (2012). Core self-evaluations a review and evaluation of the literature. Journal of Management, $38(1), 81-128$.

Claessens, B. J., Van Eerde, W., Rutte, C. G. \& Roe, R. A. (2004). Planning behavior and perceived control of time at work. Journal of Organizational Behavior, 25(8), 937-950.

Crook, H. D., Taylor, D. M., Pallant, J. F. \& Cameron, P. A. (2004). Workplace factors leading to planned reduction of clinical work among emergency physicians. Emergency Medicine Australasia, 16, 2834.

Çavuşoğlu, D. \& Savaş, A. C. (2016). Meslek liselerinde çalışan kültür dersi öğretmenlerinin karşılaştıkları sorunlar ve çözüm önerileri (Pazarcık ilçesi örneği). Çağdaş Yönetim Bilimleri Dergisi, 1, 1-13.

Deci, E. L. \& Ryan, R. M. (1991). A motivational approach to self: Integration in personality. R. A. Dienstbier (Ed.), Current theory and research in motivation, 38. Nebraska Symposium on Motivation, Perspectives on motivation içinde (ss. 237-288). Lincoln, US: University of Nebraska Press.

Demirtaş, H., Cömert, M. \& Özer, N. (2011). Öğretmen adaylarının özyeterlik inançları ve öğretmenlik mesleğine ilişkin tutumları. Eğitim ve Bilim, 36(159), 96-111.

Dinovitzer, R. \& Garth, B. G. (2007). Lawyer satisfaction in the process of structuring legal careers. Law \& Society Review, 41(1), 1-50.

Ellis, W. S. (1957). The christian lawyer as a public servant. The Christian Scholar, 40(3), 194-210.

Erdem, H., Kılınç, E. \& Demirci, D. (2016). Çalışanlarda iş yükü fazlalığın algılanan istihdam edilebilirlik üzerine etkisi. Elektronik Sosyal Bilimler Dergisi, 15(58), 772-784.

Erdoğan, Ö. \& Ergün, M. (2011). İki farklı meslek grubunda çalışan personelin denetim odağ1 ve risk eğilimi düzeylerinin karşılaştırılması. Hacettepe Üniversitesi Ĕ̈itim Fakültesi Dergisi, 40, 176-185.

Erdoğan, O. (2013). Ilköğretim (ilkokul ve ortaokul) ögretmenlerinin öz yeterlik ve başart algılarında akademik iyimserlik, umut ve mesleki haz (Yayımlanmış Yüksek Lisans Tezi). Gazi Üniversitesi Eğitim Bilimleri Enstitüsü, Ankara.
Fard, H. M., Nazari, R. \& Yar, M. Y. (2013). Structural equations modeling of fundamental communication skills with occupational satisfaction and its role on organizational commitment of the sport organizations. European Journal of Experimental Biology, 3(5), 190-196.

Flinkman, M., Leino-Kilpi, H. \& Salanterä, S. (2010). Nurses' intention to leave the profession: integrative review. Journal of Advanced Nursing, 66(7), 14221434.

Gelard, P. \& Chaman khahi, M. (2015). Examining the relationship between productivity and employees' satisfaction of payment systems in Tejarat bank. European Online Journal of Natural and Social Sciences, 4(1), 1789-1797.

Goodman, P. H. \& Januska, A. (2008). Clinical hospital medicine fellowships: Perspectives of employers, hospitalists, and medicine residents. Journal of Hospital Medicine, 3(1), 28-34.

Gökdeniz, İ. \& Merdan, E. (2011). Kişilik ile kariyer seçimi arasındaki ilişkinin incelenmesi. Aksaray Üniversitesi İktisadi ve İdari Bilimler Fakültesi Dergisi, 3(2), 23-36.

Greene, C. N. (1972). The satisfaction-performance controversy: New developments and their implications. Business Horizons, 15(5), 31-41.

Gürbüz, S., Erkuş, A. \& Sığrı, Ü. (2010). İș tatmini ve iş performansının yeni öncülü: Temel benlik değerlendirmesi. Sosyal ve Beşerî Bilimler Dergisi, 2(1), 69-76.

Hill, N. R. (2009). An empirical exploration of the occupational satisfaction of counselor educators: The influence of gender, tenure status, and minority status. Journal of Counseling \& Development, 87(1), 55-61.

Holland, J. L. (1985). Making vocational choices. Englewood Cliffs, NJ: Prentice Hall.

Hultqvist, J., Wästberg, B. \& Eklund, M. (2017). Satisfaction with daily occupations for elderly people (SDO-E)-adaptation and psychometric testing. Healthcare, 5(61), 1-10.

Imoisili, O. A. (1985). Task complexity, budget style of evaluating performance and managerial stress: An empirical Investigation (Ph.D. Dissertation). University of Pittsburgh.

Jensen J., M. \& Messersmith, J. G. (2013). Highperformance work systems and job control: Consequences for anxiety, role overload, and turnover intentions. Journal of Management, 39(6), 16991724.

Jones, O. (1998). From maturity to entrepreneurship: A 
stakeholder model of innovation. Creativity and Innovation Management, 7(2), 107-114.

Judge, T.A., Locke, E.A. \& Durham, C.C. (1997). The dispositional causes of job satisfaction: A core evaluations approach", Research in Organizational Behavior, 19, 151-188.

Judge, T. A., Erez, A. \& Bono, J. E. (1998). The power of being positive: The relation between positive selfconcept and job performance. Human Performance, 11(2-3), 167-187.

Judge, T. A., Bono, J. E. \& Locke, E. A. (2000). Personality and job satisfaction: The mediating role of job characteristics. Journal of Applied Psychology, $85,237-249$.

Judge, T. A. \& Bono, J. E. (2001). Relationship of core self-evaluations traits-self-esteem, generalized selfefficacy, locus of control, and emotional stabilitywith job satisfaction and job performance: A metaanalysis. Journal of Applied Psychology, 86(1), 8092.

Judge, T. A., Erez, A., Bono, J. E. \& Thoresen, C. J. (2003). The core self- evaluations scale: Development of a measure. Personnel Psychology, 56(2), 303-331.

Judge, T. A., Van Vianen, A. E. M. \& De Pater, I. E. (2004) Emotional stability, core self-evaluations, and job outcomes: A review of the evidence and an agenda for future research. Human Performance, 17(3), 325-346.

Judge, T. A., Bono, J. E., Erez, A. \& Locke, E. A. (2005). Core self-evaluations and job and life satisfaction: The role of self-concordance and goal attainment. Journal of Applied Psychology, 90(2), 257-268.

Judge, T. A. (2009). Core self-evaluations and work success. Current Directions in Psychological Science, 18(1), 58-62.

Karacaoğlu, K. \& Çetin, İ. (2015). İş yükü ve rol belirsizliğinin çalıșanların tükenmişlik düzeyleri üzerine etkisi: AFAD Örneği. Nevşehir Hacı Bektaş Veli Üniversitesi SBE Dergisi, 5(1), 46-69.

Karaçam, A. \& Pulur, A. Hakemler için mesleki haz ölçeği: Geçerlik ve güvenirlik çalışmasıHİMHÖ. Gaziantep Üniversitesi Spor Bilimleri Dergisi, 3(2), 35-45.

Kohut, H. (1977), The restoration of the self. New York: International Universities Press.

Koreki, A., Nakagawa, A., Abe, A., Ikeuchi, H., Okubo, J., Oguri, A., Orimo, K., Katayama, N., Sato, H., Shikimoto, R., Nishiyama, G., Nogami, W., Haki, K., Hayashi, T., Fukagawa, Y., Funaki, K., Matsuzawa, M, Matsumoto, A., \& Minura, M. (2015). Mental Health of Japanese Psychiatrists: The relationship among level of occupational stress, satisfaction and depressive symptoms. BMC Research Notes, 8(96), 19.

Kuzgun, Y. (1994). Çağdaş insanın en önemli kararı meslek seçimi. Bilim ve Teknik, 325, 50-54.

Laschinger, H. K. S., Purdy, N. \& Almost, J. (2007). The impact of leader-member exchange quality, empowerment, and core self-evaluation on nurse manager's job satisfaction. Journal of Nursing Administration, 37(5), 221-229.

Lounsbury, J. W., Loveland, J. M., Sundstrom, E. D., Gibson, L. W., Drost, A. W. \& Hamrick, F. L. (2003). An investigation of personality traits in relation to career satisfaction. Journal of Career Assessment, 11(3), 287-307.

Lounsbury, J. W., Moffitt, L., Gibson, L. W., Drost, A. W., \& Stevens, M. (2007). An investigation of personality traits in relation to job and career satisfaction of information technology professionals. Journal of Information Technology, 22, 174-183.

Lu, H., While, A. E., \& Barriball, K. L. (2005). Job satisfaction among nurses: A literature review. International Journal of Nursing Studies, 42(2), 211-227.

Mansur, N. N. A., Ahmed, M. A., Ishaq, H. M., Ahmad, J. \& Ali, G. (2011). Personality and organizational outcomes (Organizational culture as a moderator). International Journal of Academic Research, 3(6), 54-59.

Martin, R., Thomas, G., Charles, K., Epitropaki, O. \& McNamara, R. (2005). The role of leader-member exchanges in mediating the relationship between locus of control and work reactions. Journal of Occupational and Organizational Psychology, 78(1), 141-147.

Maslach, C. \& Leiter, M. P. (1997). The Truth about Burnout. New York, NY: Jossey-Bass.

McElhaney, J. W. (1982). Getting along with judges. Litigation, 9, 41-44.

McKenzie, S. C. (1992). Storytelling: A different voice for legal education. The University of Kansas Law Review, 41, 251-269.

Meydan, C. H. \& Şeşen, H. (2015). Yapısal Eşitlik Modellemesi Amos Uygulamaları. Ankara: Detay Yayınc1lı.

Mezuk, B., Bohnert, A. B., Ratliff, S. \& Zivin, K. (2011). Job strain, depressive symptoms, and drinking behavior among older adults: Results from the health and retirement study. The Journals of Gerontology: Series B: Psychological Sciences and Social Sciences, 66B(4), 426-434 
Morgan, C. T. (1998). Psikolojiye Giriş. Hüsnü Arıcı vd. (Çev). Ankara: Hacettepe Üniversitesi Psikoloji Bölümü Yayınları.

Morgan, W. J. (2010). What, exactly, is occupational satisfaction? Journal of Occupational Science, 17(4), 216-223.

Mount, M. K., Barrick, M. R., Scullen, S.M. \& Rounds, J. (2005). Higher-order dimensions of the big five personality traits and the big six vocational interest types. Personnel Psychology, 58(2), 447-478.

Odabaş, H. (2014). Atatürk üniversitesi bilgi ve belge yönetimi bölümü öğrencilerinin bölüme ve disipline karşı tutum ve davranışları. Ankara Üniversitesi Bilgi ve Belge Yönetimi Bölümü 60. Yll Armağan Kitabl, 60, 129-142.

Omaç Sönmez, M. \& Sevindik, F. (2013). Sağlıkta dönüşümün sağlık personeli üzerine etkisi: Aile sağlığı elemanı olmak. TAF Preventive Medicine Bulletin, 12(1), 43-48.

Palahang, H., Soltani, I., Nikfarjam, M. \& Sharifi, A. (2012). The effect of occupational satisfaction in mobarakeh steel company employees. Life Science Journal-Acta Zhengzhou University Overseas Edition, 9(4), 5553-5557.

Peng, J., Li, D., Zhang, Z., Tian, Y., Miao, D., Xiao, W. \& Zhang, J. (2016). How can core self-evaluations influence job burnout? The key roles of organizational commitment and job satisfaction. Journal of Health Psychology, 21(1), 5059.

Pillay, R. (2009). Work satisfaction of professional nurses in south Africa: A comparative analysis of the public and private sectors. Human Resources for Health, 7(15), 1-10.

Punnakitikashem, P., Rosenberger, J. M. \& Behan, D. B. (2008). Stochastic programming for nurse assignment. Computational Optimization and Applications, 40(3), 321-349.

Raj, A. \& Dean, K. E. (2005). Burnout and depression among catholic priests in India. Pastoral Psychology, 54(2), 157-171.

Reineck, C. \& Furino, A. (2005). Nursing career fulfillment: Statistics and statements from registered nurses. Nursing Economics, 23(1), 25-30.

Richard, L. (2002). Psychological type and job satisfaction among practicing lawyers in the United States. Capital University Law Review, 29(4): 9791078 .

Rodríguez, M. \& Martín, N. (2017). Workplace bullying occurrence in alternative organizational milieus: ıdentifying risk groups among distinct occupations from the organizational behavior and management perspective. Universidad de Córdoba, UCOPress.

Rubio-Valdehita, S., López-Núñez, M. I., López-Higes, R. \& Díaz-Ramiro, E. M. (2017). Development of the CarMen-Q questionnaire for mental workload assessment. Psicothema, 29(4), 570-576.

Rumpf, C. (2010). Türk hukuku ile mukayese edildiğinde Almanya'da ve Avrupa'da avukatların reklam yapma hakk1. Ankara Barosu Dergisi, (1), 145-166.

Shanafelt, T. \& Dyrbye, L. (2012). Oncologist burnout: Causes, consequences, and responses. Journal of Clinical Oncology, 30(11), 1235-1241.

Shawer, S. (2010). Classroom-level teacher professional development and satisfaction: Teachers learn in the context of classroom-level curriculum development. Professional Development in Education, 36(4), 597620.

Srivastava, A., Locke, E. A., Judge, T. A. \& Adams, J. W. (2010). Core self-evaluations as causes of satisfaction: The mediating role of seeking task complexity. Journal of Vocational Behavior, 77(2), 255-265.

Süral Özer, P. \& Tozkoparan, G. (2013). Öz benlik değerlendirmeleri ile iş ve yaşam doyumu ilişkisinin sorgulanmasına yönelik görgül bir araştırma. Journal of Yasar University, 8(30), 4933-4947.

Şahin, H. \& Şahingöz, S. A. (2013). The relationship between personnel workload and work satisfaction within accommodation and nutrition establishments. American International Journal of Social Science, 2(3), 10-18.

Şeşen, H. (2010). Öncülleri ve sonuçlart ile örgüt içi girișimcilik: Türk savunma sanayinde bir araștırma (Yayımlanmamış Doktora Tezi). KHO Savunma Bilimleri Enstitüsü, Ankara.

Şimşek, E. \& Aktaş, H. (2014). Örgütsel sessizlik ile kişilik ve yaşam doyumu etkileşimi: Kamu sektöründe bir araştırma. Anadolu Üniversitesi Sosyal Bilimler Dergisi, 14(2), 121-136.

Tabachnick, B. G. \& Fidell, L. S. (2013). Using multivariate statistics. (6.th Ed.). Boston. MA Pearson.

Tavousi, M. N. (2015). Dispositional effects on job stressors and job satisfaction: The role of core evaluations. Procedia-Social and Behavioral Sciences, 190, 61-68.

Tischler, L., Giambatista, R., McKeage, R. \& McCormick, D. (2016). Servant leadership and its relationships with core self-evaluation and job satisfaction. The Journal of Values-Based Leadership, 9(1), 1-20. 
Türkiye Barolar Birliği, http://www.barobirlik.org.tr/Detay79803.tbb, Erişim Tarihi: 10.05.2018.

Uslu, M. (2013). Pedagojik formasyon öğrencilerinin kişilik özellikleri ve öğretmenlik mesleğine yönelik tutumları arasındaki ilişkinin incelenmesi. Journal of Human Sciences, 10(2), 233-245.

Van Steenbergen, E. F., Kluwer, E. S. \& Karney, B. R. (2011). Workload and the trajectory of marital satisfaction in newlyweds: Job satisfaction, gender, and parental status as moderators. Journal of Family Psychology, 25(3), 345-355.

Velada, R. \& Caetano, A. (2007). Training transfer: The mediating role of perception of learning. Journal of European Industrial Training, 31(4), 283-296.

Walker, G. A. (1986). Burnout: From metaphor to ideology. Canadian Journal of Sociology, 11, 35-55.

Weiner, J. S. (1982). The measurement of human workload. Ergonomics, 25(11), 953-965.

Wilcock, A. (2006). An Occupational Perspective of Health, USA: Slack Incorporated.

Xiao, W., Zhou, L., Wu, Q., Zhang, Y., Miao, D., Zhang, J. \& Peng, J. (2014). Effects of person-vocation fit and core self-evaluation on career commitment of medical university students: The mediator roles of anxiety and career satisfaction. International Journal of Mental Health Systems, 8(8), 1-6.

Yang, Y. S. (2007). Study of the development of industrial relations structure in foreigninvested enterprises in China. Journal of Information and Optimization Sciences, 28(6), 881-903.

Yılmaz, A. \& Ekici, S. (2006). Örgütsel yaşamda kamu çalışanlarının örgütsel stres kaynakları üzerine bir araştırma. Süleyman Demirel Üniversitesi İktisadi ve İdari Bilimler Fakültesi Dergisi, 11(1), 31-58.

Yüksel, İ. (2003). İş stresi, işe bağlllık ve iş doyumu arasındaki ilişkinin analizi (Teknisyenlere yönelik bir uygulama). Atatürk Üniversitesi İktisadi ve İdari Bilimler Dergisi, 17, 213-224. 